\title{
Mollusc assemblage in an urban bay nearby a marine extractive reserve, Florianópolis - SC, Brazil
}

\author{
Ana Luiza Gandara-Martins ${ }^{1,3}$ \& Tito Cesar Marques de Almeida ${ }^{2}$ \\ ${ }^{1}$ Laboratório de Ecologia de Praias Arenosas, Centro de Estudos do Mar, \\ Universidade Federal do Paraná - UFPR, Av. Beira Mar, s/n, CP 61, CEP 83255-971, \\ Pontal do Paraná, PR, Brazil. http://www.cem.ufpr.br/ \\ ${ }^{2}$ Laboratório de Ecologia de Comunidades Aquáticas, Centro Tecnológico da Terra e do Mar, \\ Universidade do Vale do Itajai - UNIVALI, Rua Uruguai, 458, Bloco 20, sala 144, Centro, \\ CEP 88302-202, Itajai, SC, Brazil. http://www.univali.br/cttmar \\ ${ }^{3}$ Corresponding author: Ana Luiza Gandara-Martins, e-mail: analumar@gmail.com
}

GANDARA-MARTINS, A.L. \& ALMEIDA, T.C.M. Molluse assemblage in an urban bay nearby a marine extractive reserve, Florianópolis - SC, Brazil. 13(2): http://www.biotaneotropica.org.br/v13n2/en/ abstract?article+bn01813022013

\begin{abstract}
Marine Extractive Reserve (RESEX), where several human activities are performed. Uni and multivariate analyses were conducted considering spatial (six sampling stations) and temporal scale (30 surveys from 2002 to 2008) and two associations were recognized. We identified 48 species from 28 families belonging to four classes: Bivalvia, Gastropoda, Polyplacophora, and Scaphopoda. The Sand Tidal Flat association had a contribution of more than $90 \%$ of Anomalocardia brasiliana (Gmelin, 1791) as well as a higher diversity and similarity among surveys. The Mud Bottom association had a lower similarity among surveys due to the low abundance of species. The feeding habits of molluscs were different between the associations. The climate and the fauna followed a seasonal pattern, with low variance over years. The highest diversity was detected at the end of a highway construction, indicating a rapid recolonization, probably due to the proximity to a protected area. We highlight the need to the conservation of sand tidal flats, mostly because of their high diversity, location in a transitional zone between marine, freshwater, and terrestrial ecosystems (connected with mangrove forests), in addition to the economic importance, and anthropogenic pressure.
\end{abstract}

Keywords: sand tidal flat, mud bottom, feeding habits, Anomalocardia brasiliana, Southern Brazil.

GANDARA-MARTINS, A.L. \& ALMEIDA, T.C.M. Assembleia de moluscos em uma Baia urbana próxima a uma reserva extrativista marinha, Florianópolis - SC, Brasil. Biota Neotrop. 13(2): http://www.biotaneotropica. org.br/v13n2/pt/abstract?article+bn01813022013

Resumo: Descrevemos a variação espaço-temporal da assembleia de moluscos em uma baía costeira urbana próxima a uma Reserva Extrativista Marinha (RESEX), onde várias atividades humanas são realizadas. Análises uni e multivariadas foram realizadas, considerando as escalas espacial (seis estações de amostragem) e temporal (30 campanhas entre 2002 e 2008). Um total de 48 espécies foram identificadas, pertencentes a 28 famílias e distribuídas em 4 classes: Bivalvia, Gastropoda, Polyplacophora e Scaphopoda. Duas associações foram reconhecidas. A associação Planície Arenosa teve uma contribuição de mais de $90 \%$ de Anomalocardia brasiliana (Gmelin 1791) e maior diversidade e similaridade entre as campanhas. A associação Fundo Lamoso teve menor similaridade entre as campanhas, devido à baixa abundância de espécies. O hábito alimentar dos moluscos que compõem as associações também foi diferente entre as associações. O clima durante o período estudado apresentou um padrão sazonal, com pouca variação entre os anos, que foi seguido pela fauna. A maior diversidade foi detectada concomitantemente ao fim da construção de uma rodovia (Via Expressa Sul), evidência de uma rápida recolonização, possivelmente associada à proximidade de uma área protegida (RESEX). Ressaltamos a necessidade de conservação das planícies arenosas entre-marés, principalmente devido a sua alta diversidade, localização em zonas de transição entre os ecossistemas de água doce, marinho e terrestre (conectados a florestas de mangue), importância econômica e pressão antrópica.

Palavras-chave: planície arenosa, fundo lamoso, hábitos alimentares, Anomalocardia brasiliana, Sul do Brasil. 


\section{Introduction}

The National System for Conservation Units from Brazil defines and regulates the categories of protected areas, and it is basically divided into two groups: Areas of complete protection and areas of sustainable use. The extractive reserve (RESEX) is a category from the sustainable use group and is designated for the subsistence of locals based on controlled extraction. The Marine Extractive Reserve (RESEX) of Pirajubaé is nearby an urban bay, located on a coastal island in southern Brazil. The main resource is the bivalve Anomalocardia brasiliana (Gmelin 1791) -Veneridae that sustain socially, economically and culturally a fishing community of about 103 officially registered fishermen (Ribas \& Zuculoto 2012, Vizinho \& Tognella-de-Rosa 2010).

Similar to the urban bays around the world, this bay is under severe pressure of economic development. Some activities such as drainage (Newell et al. 1998, Bemvenuti et al. 2005), disposal of sediments (Bolam et al. 2006, Vivan et al. 2009), construction of permanent structures (Skilleter \& Warren 2000), domestic and industrial sewage (Guerra-García \& García-Gómez 2004, Cannicci et al. 2009), and fishing (Collie et al. 2000, Gaspar et al. 2003, Gray et al. 2006) are well known to affect benthic assemblages. Among the organisms that compose the benthic macrofauna, molluscs may rapidly respond to impacts such as burial and/or suspension of fine sediments (Morton 1996), enrichment with organic matter from sewage (Inglis \& Kross 2000, Guerra-García \& García-Gómez 2004, Whomersley et al. 2007, Cannicci et al. 2009), and commercial exploitation (Brazeiro \& Defeo 1999).

Some of these activities happened or continue to happen at this bay, such as drainage/disposal of sediments and construction of a highway on its margin (from 1996 to 2005), domestic sewage discharge, and fishing activities (Pezzuto \& Echternacht 1999, Schettini et al. 2000, Souza et al. 2012, Vizinho \& Tognella-de-Rosa 2010). Although the RESEX of Pirajubae is a natural conservation unit and sustains part of local economy, the highway construction and urban expansion did not take into account the environmental, social, economic, and cultural aspects. Most of the fishermen complain about a decrease in the $A$. brasiliana production and sale after the highway construction and also about the problems from domestic sewage input (Vizinho \& Tognella-de-Rosa 2010).

Thus, the objective of this study was to assess the molluscan assemblage composition and structure on a coastal urban bay near the Pirajubaé RESEX over a 7 year monitoring effort. We expected that mollusc assemblages have higher species diversity closer to the RESEX, where a sand tidal flat is located, and that this diversity is under fluctuations due to human activities.

\section{Material and Methods}

\section{Study area}

Sampling was conducted in a shallow embayment (Saco dos Limões) inside an urban bay (South Bay) within $7 \mathrm{~km}^{2}$ area between the mainland and the coastal island of Florianópolis, Southern Brazil (27 $38^{\prime} \mathrm{S}$ and $48^{\circ} 33^{\prime} \mathrm{W}$ ) (Figure 1). This embayment is approximately $1-\mathrm{m}$ deep in the southern section and slightly deeper at the northern section, with low hydrodynamic energy. A sand tidal flat is located on its southern margin, which together with an adjacent mangrove forest, composes the RESEX, the first of its category in Brazil. This area is one of the main sources of the bivalve A. brasiliana in Brazil, where exploitation is made up by artisanal fishing (Pezzuto et al. 2010). The local sediment is characterized by clay and silty clay at the central, northern, and northwestern area of the embayment. At the tidal flat in the southwest section, sediment is composed basically of sand and silty sand. The dispersion of sandy sediments in the latter areas coincides with the biogenic debris distribution (Schettini et al. 2002).

The tide in Florianópolis, Santa Catarina, is microtidal (mean range: $0.8 \mathrm{~m}$ ) and of the mixed discontinuous semidiurnal type. As a consequence of urban spread and the rough coastline, this bay had its eastern shore filled with earth for a highway embankment. Its building was made with sediment dredged from the most external sector of the tidal flat, reducing its area by almost 50\% (Pezzuto \& Echternacht 1999). This activity lasted for about 10 years (1996-2005) and had changed the entire morphology of the eastern shore. Consequently, almost all margins of the embayment are urbanized and receive rain

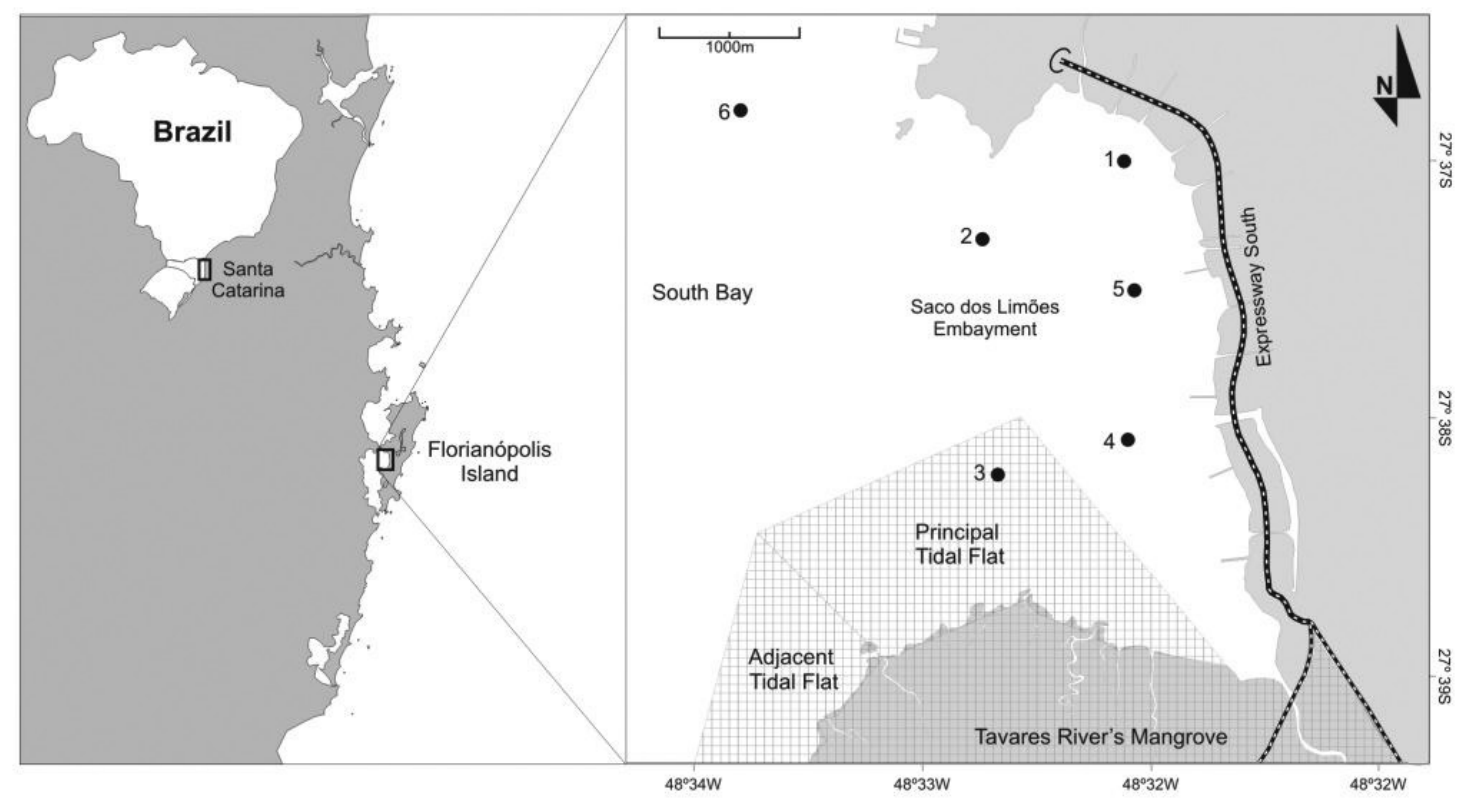

Figure 1. Map of South Bay, Florianópolis Island, Santa Catarina State, Brazil. Sampling locations numbered from 1 to 6 . The hatched area refers to the Marine Extractive Reserve of Pirajubaé (Pirajubaé RESEX), where the sand tidal flat is located. Station 3 is the only station within this tidal flat. 
drainage contaminated with domestic sewage in several sections (Schettini et al. 2000, Vizinho \& Tognella-de-Rosa 2010).

\section{Sampling and data treatment}

A total of 30 surveys were carried out between 2002 and 2008. In each survey, four samples were collected at six stations along the embayment area (Figure 1). Each sample was collected with a Van Veen grabber of $0.025 \mathrm{~m}^{2}$ surface area. Samples were sieved through a $0.05 \mathrm{~mm}$ mesh and the organisms were fixed in a $4 \%$ formaldehyde solution. All organisms were sorted and the molluscs were identified to the lowest taxonomic level (Arruda \& Domaneschi 2005, Simone 2006 , Rios 2009) and preserved in 70\% alcohol. The feeding habit classification followed Arruda et al. (2003) and Rios (2009).

Additional sediment samples for granulometric analyses were collected at 5 surveys (October 2003, December 2003, March 2004, December 2007, and August 2008). Meteorological data of mean rainfall and minimum, average, and maximum temperatures for all months between 2002 and 2008 were provided by the Brazilian Company for Agricultural Research and Rural assistance of Santa Catarina (EPAGRI).

\section{Data analysis}

Sediment fractions were estimated by standard mechanical sieving grain analysis. A portion of sediment was exposed to acid dissolution using hydrochloric acid $(\mathrm{HCl})$ at $10 \%$ volume to quantify carbonate concentrations. Next, concentration of organic matter was set after burning $5 \mathrm{~g}$ of the sediment in a muffle furnace for 8 hours at $800{ }^{\circ} \mathrm{C}$. Granulometric parameters were acquired using the software Sysgran version 3.0, following the method of Folk and Ward (1957). In order to check the variability in composition of sediment among stations, a Principal Component Analysis (PCA) was performed on the percentages of granulometric fractions and not with statistical parameters due to the bimodal distribution of some samples (Legendre \& Legendre 1998).

A non-parametric permutational multivariate analysis of variance (PERMANOVA) (Anderson 2001, 2005, McArdle \& Anderson 2001) was carried out to test temporal and spatial differences and to identify the molluscan associations with Bray-Curtis distances calculated from the abundance matrix of the molluscs $[\log (\mathrm{x}+1)$ transformed]. A dummy variable of 1 was added to deal with the zero values. Pair-wise a posteriori tests were also carried out as a multivariate version of the t-statistic based on distances (Anderson 2005). An ordination by non-metric multidimensional scaling (n-MDS) was used to illustrate the results. A similarity percentage (SIMPER) was carried out to identify the species contribution that provided the discriminating features between associations (PRIMER 6.0, Clarke \& Warwick 2001).

After associations' recognition, their structure was analyzed by the following diversity indexes: Species richness (S), number of individuals $/ 0.025 \mathrm{~m}^{2}$ area; Shannon Wiener diversity (Nats/ individual), and Pielou's Equitability. These numerical descriptors were calculated for each sampling unit with the software PRIMER 6.0 (Clarke \& Warwick 2001) and tested through analysis of variance (ANOVA) using R software (version 2.15.1; R development... 2012) to evaluate the temporal and spatial variation between associations. Data were $\log (\mathrm{x}+1)$ transformed to reduce heterogeneity of variances whenever appropriate. When differences were detected ( $\mathrm{p}<0.05)$, a posteriori LSD test was applied (Underwood 1997). Premises of this analysis were tested using Kolmogorov-Smirnov test for normality and Cochran's test for homogeneity of variance. It was accepted at $p>0.05$. Species accumulation curves by area were set to compare species diversity between associations.

\section{Results}

\section{Sediment and meteorological characterization}

The embayment was composed mainly of silty sediment very poorly selected, with mostly negative asymmetry, platykurtic, or mesocurtic curves (reinforcing the poor selection of the sediment) and with a high concentration of organic matter (5.2-15.1 g) and low carbonates (4.68-9.16 g). The tidal flat, represented by station 3 , had distinct characteristics, with more than $80 \%$ of fine sand in all samples; poorly selected, negative asymmetry, had leptokurtic curves, with low concentration of organic material (1.02-2.03 g) and higher levels of carbonate (12.93-18.79 g).

The PCA analysis extracted two axes and explained $83 \%$ of all variation. The first one accounted for $55 \%$ of variation and separated the samples into two groups (Figure 2). The positive area was mainly because of the presence of sand and gravel, where all samples of station 3 and few from stations 4 and 5 in 2007 and 2008 were

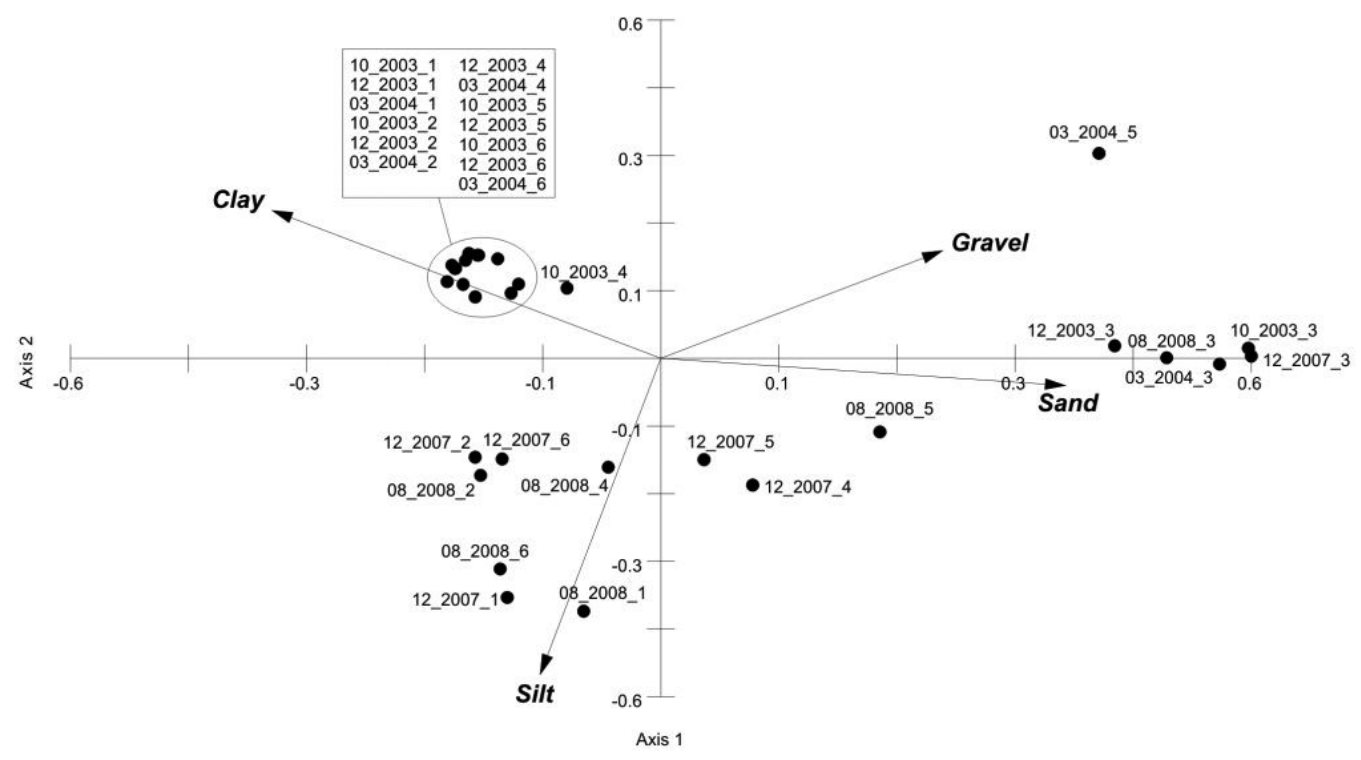

Figure 2. Principal Component Analysis (PCA). Sediment size percentage as the vectors of five surveys (10/2003, 12/2003, 03/2004, 12/2007, 08/2008) represented by full dots (month_year_station). 
concentrated. The negative area had the remaining stations with fine sediment. Axis 2 was responsible for $28 \%$ of variation with high percentage of clay and gravel on 2003 and 2004 surveys and silt on 2007 and 2008 surveys (Figure 2).

Rainfall followed the seasonal pattern of southern coast of Brazil, higher in summer months and lower in the winter ones for most years. Between 2002 and 2003, there was an El Niño event, when the mean temperatures were higher and the rainfall was lower than average. Between 2007 and 2008, there was a La Niña period, with higher rainfall and lower temperature values (Figure 3). The winter in 2005 had a higher rainfall volume, and, together with 2006 winter, it had higher mean temperature values (Figure 3 ).

\section{Mollusc assemblage}

A total of 1846 organisms were collected and classified into 48 species within 28 families belonging to four classes: Bivalvia, Gastropoda, Polyplacophora, and Scaphopoda (Table 1). Bivalvia had 31 species and also the highest abundance $(74.9 \%)$ with $A$. brasiliana, responsible for more than $50 \%$ of individuals, followed by Tellina lineata and Macoma uruguayensis, which together accounted for $9 \%$ of total individuals. Gastropoda was represented by 16 species and $21.1 \%$ of total abundance, primarily represented by Cylichna verrilli and Crepidula pyguaia. The classes Polyplacophora (3.9\%) and Scaphopoda $(0.1 \%)$ had only one species each (Table 1$)$. The species Volvulella texasiana had its distribution extended to southern Brazil.

As observed for sediment, station 3 differed from others in multivariate analysis. PERMANOVA showed differences in time $\left(\mathrm{F}_{29,719}=2.03 ; \mathrm{p}=0.0001\right)$, space $\left(\mathrm{F}_{5,719=} 41.6 ; \mathrm{p}=0.0001\right)$, as well as in its interaction $\left(\mathrm{F}_{145,719=} 3.1 ; \mathrm{p}=0.0001\right)$. The n-MDS plots illustrated two distinct associations: A Sand Tidal Flat association represented by station 3 and a Mud Bottom association represented by other stations. Mud Bottom association was composed of stations with low abundance and variable species composition, while Sand Tidal Flat association had higher abundance and diversity (Figure 4).

The species contribution that primarily provided the discriminating features between associations (SIMPER) showed low similarity between samples of Mud Bottom association, mainly composed by M. uruguayensis, C. verrilli, and T. divisus. On the other hand, Sand Tidal Flat association had a higher abundance and similarity among samples, with $A$. brasiliana and $T$. lineata primarily responsible for this similarity (Table 2). The community indexes (richness, total density, diversity, and equitability) had significant differences ( $\mathrm{p}<$ 0.05 ) for all levels (association, surveys, and interactions between factors) in ANOVA analysis (Table 3). Sand Tidal Flat association had higher richness, diversity, and density values than did Mud Bottom (Figure 5a-d). In addition, winter months showed higher values of such indexes until the year 2005. From 2005 up to 2008 richness, and consequently diversity, increased with no seasonal pattern. Surveys in December 2004 and August 2005 had higher diversity in mud bottom sites (Figure 5).

The higher density in Sand Tidal Flat association was related to A. brasiliana, which was the most abundant and dominant species at station 3 and contributed to more than $90 \%$ of the total abundance at this site (Figure 6). The abundance peaks at this association were found mostly during winter and spring months. After 2006 winter, a decrease in abundance of $A$. brasiliana was observed along with
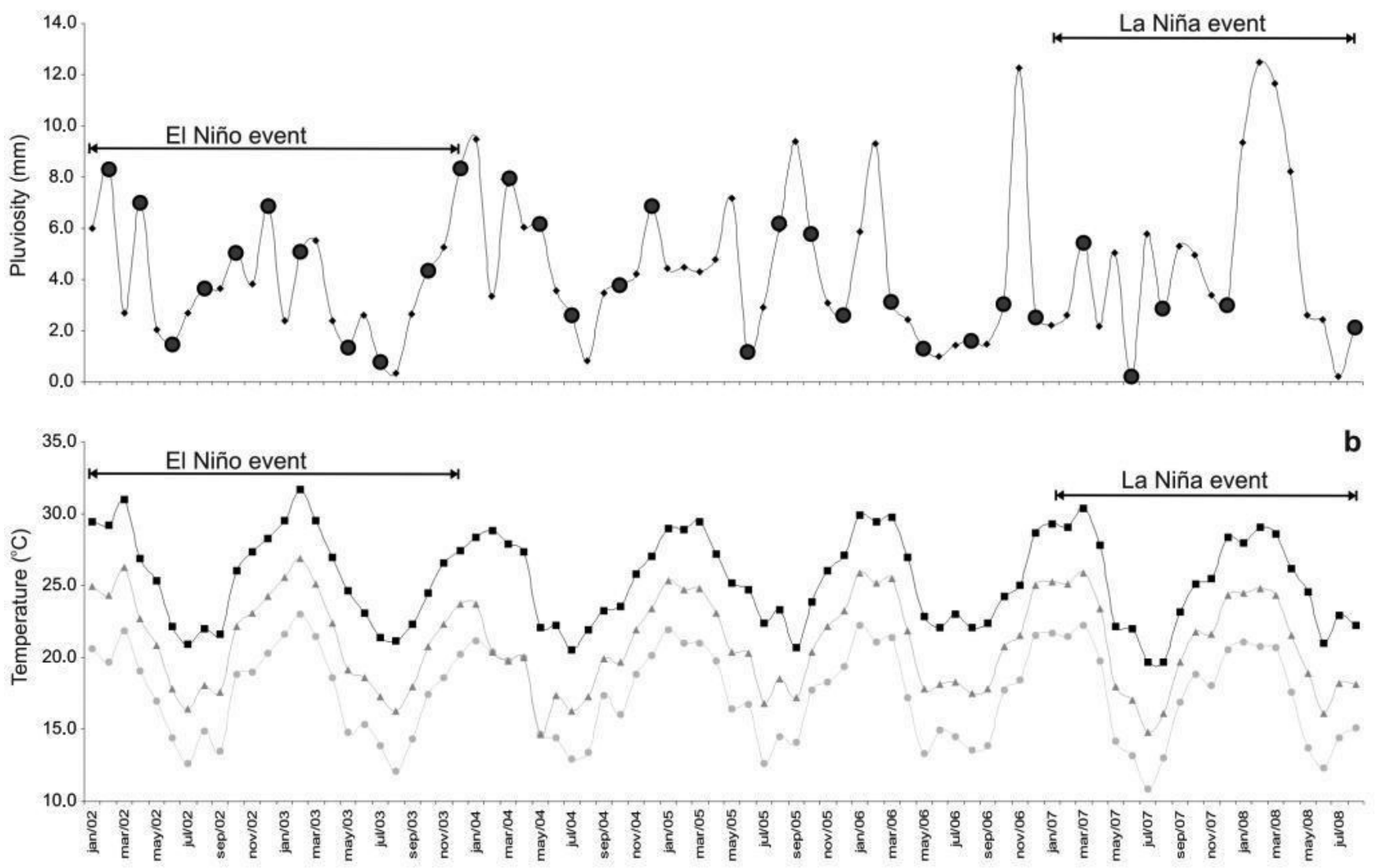

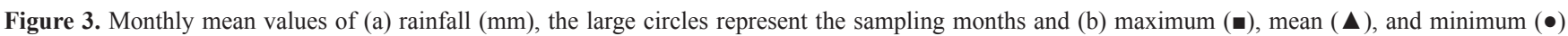
temperature $\left({ }^{\circ} \mathrm{C}\right)$ values from January 2002 to August 2008. 
Mollusc assemblage in an urban bay

Table 1. Taxonomic list with respective total and relative abundance of phylum Mollusca from South Bay - Florianópolis Island in surveys between 2002 and 2008.

\begin{tabular}{|c|c|c|c|c|}
\hline Class & Family & Species & $\begin{array}{c}\text { Total } \\
\text { Abundance }\end{array}$ & $\begin{array}{c}\text { Relative } \\
\text { Abundance }\end{array}$ \\
\hline Polyplacophora & - & Polyplacophora sp & 72 & 3.90 \\
\hline \multirow[t]{16}{*}{ Gastropoda } & Neritidae & Neritina virginea (Linnaeus, 1758) & 13 & 0.70 \\
\hline & Hydrobiidae & Heleobia australis (d' Orbigny, 1835) & 3 & 0.16 \\
\hline & Cerithiidae & Cerithium atratum (Born, 1778) & 15 & 0.81 \\
\hline & Calyptraeidae & Bostrycapulus odites Collin, 2005 & 7 & 0.38 \\
\hline & Calyptraeidae & Crepidula pyguaia Simone, 2006 & 79 & 4.28 \\
\hline & Calyptraeidae & Calyptrea centralis (Conrad, 1841) & 1 & 0.05 \\
\hline & Naticidae & Natica pusilla Say, 1822 & 2 & 0.11 \\
\hline & Columbellidae & Anachis sp & 8 & 0.43 \\
\hline & Nassaridae & Nassarius vibex (Say, 1822) & 15 & 0.81 \\
\hline & Olividae & Olivella $\mathrm{sp}$ & 2 & 0.11 \\
\hline & Pyramidellidae & Eulimastoma cf. surinamense Altena, 1975 & 2 & 0.11 \\
\hline & Cylichnidae & Cylichna verrilli Dall, 1889 & 174 & 9.43 \\
\hline & Cylichnidae & Acteocina candei (d'Orbigny, 1841) & 48 & 2.60 \\
\hline & Retusidae & Volvulella texasiana Harry, 1967 & 4 & 0.22 \\
\hline & Bullidae & Bulla striata Bruguiere, 1792 & 15 & 0.81 \\
\hline & - & Opisthobranchia sp & 1 & 0.05 \\
\hline Scaphopoda & Dentaliidae & Dentaliidae sp & 2 & 0.11 \\
\hline \multirow[t]{31}{*}{ Bivalvia } & Nuculidae & Nucula semiornata d'Orbigny, 1846 & 19 & 1.03 \\
\hline & Mytilidae & Mytella guyanensis (Lamarck, 1819) & 5 & 0.27 \\
\hline & Ostreidae & Crassostrea sp1 & 17 & 0.92 \\
\hline & Pectinidae & Chlamys cf. bavay (Dautzenberg, 1900) & 1 & 0.05 \\
\hline & Lucinidae & Lucina pectinata (Gmelin, 1791) & 3 & 0.16 \\
\hline & Lucinidae & Codakia pectinella C.B. Adams, 1852 & 23 & 1.25 \\
\hline & Ungulinidae & Diplodonta danieli Klein, 1967 & 3 & 0.16 \\
\hline & Mactridae & Mactra fragilis Gmelin, 1791 & 1 & 0.05 \\
\hline & Mactridae & Mactra janeiroensis E.A. Smith, 1915 & 2 & 0.11 \\
\hline & Mactridae & Mulinia cleriana (d'Orbigny, 1846) & 1 & 0.05 \\
\hline & Tellinidae & Tellina versicolor De Kay, 1843 & 19 & 1.03 \\
\hline & Tellinidae & Tellina lineata Turton, 1819 & 85 & 4.60 \\
\hline & Tellinidae & Tellina trinitatis (Tomlin, 1929) & 4 & 0.22 \\
\hline & Tellinidae & Macoma constricta (Bruguière, 1792) & 1 & 0.05 \\
\hline & Tellinidae & Macoma uruguayensis (E.A. Smith, 1885) & 80 & 4.33 \\
\hline & Semelidae & Abra lioica (Dall, 1881) & 15 & 0.81 \\
\hline & Semelidae & Ervilia nitens (Montagu, 1806) & 2 & 0.11 \\
\hline & Psammobiidae & Tagelus divisus (Spengler, 1794) & 49 & 2.65 \\
\hline & Veneridae & Chione cf. cancelata (Linnaeus, 1767) & 11 & 0.60 \\
\hline & Veneridae & Anomalocardia brasiliana (Gmelin, 1791) & 976 & 52.87 \\
\hline & Veneridae & Protothaca pectorina Lamarck, 1818 & 14 & 0.76 \\
\hline & Veneridae & Transenella cf. stimpsoni Dall, 1902 & 1 & 0.05 \\
\hline & Veneridae & Pitar fulminatus (Menke, 1828) & 2 & 0.11 \\
\hline & Veneridae & Dosinia concentrica (Born, 1778) & 1 & 0.05 \\
\hline & Veneridae & Cyclinella tenuis (Récluz, 1852) & 5 & 0.27 \\
\hline & Petricolidae & Petricola $\mathrm{sp} 1$ & 3 & 0.16 \\
\hline & Myidae & Sphenia antillensis Dall and Simpson, 1901 & 21 & 1.14 \\
\hline & Corbulidae & Corbula caribaea d'Orbigny, 1853 & 12 & 0.65 \\
\hline & Corbulidae & Corbula lyoni Pilsbry, 1897 & 3 & 0.16 \\
\hline & Corbulidae & Corbula cubaniana d'Orbigny, 1853 & 2 & 0.11 \\
\hline & Thraciidae & Thracia cf. distorta Montagu, 1808 & 2 & 0.11 \\
\hline Total & & & 1846 & 100.0 \\
\hline
\end{tabular}




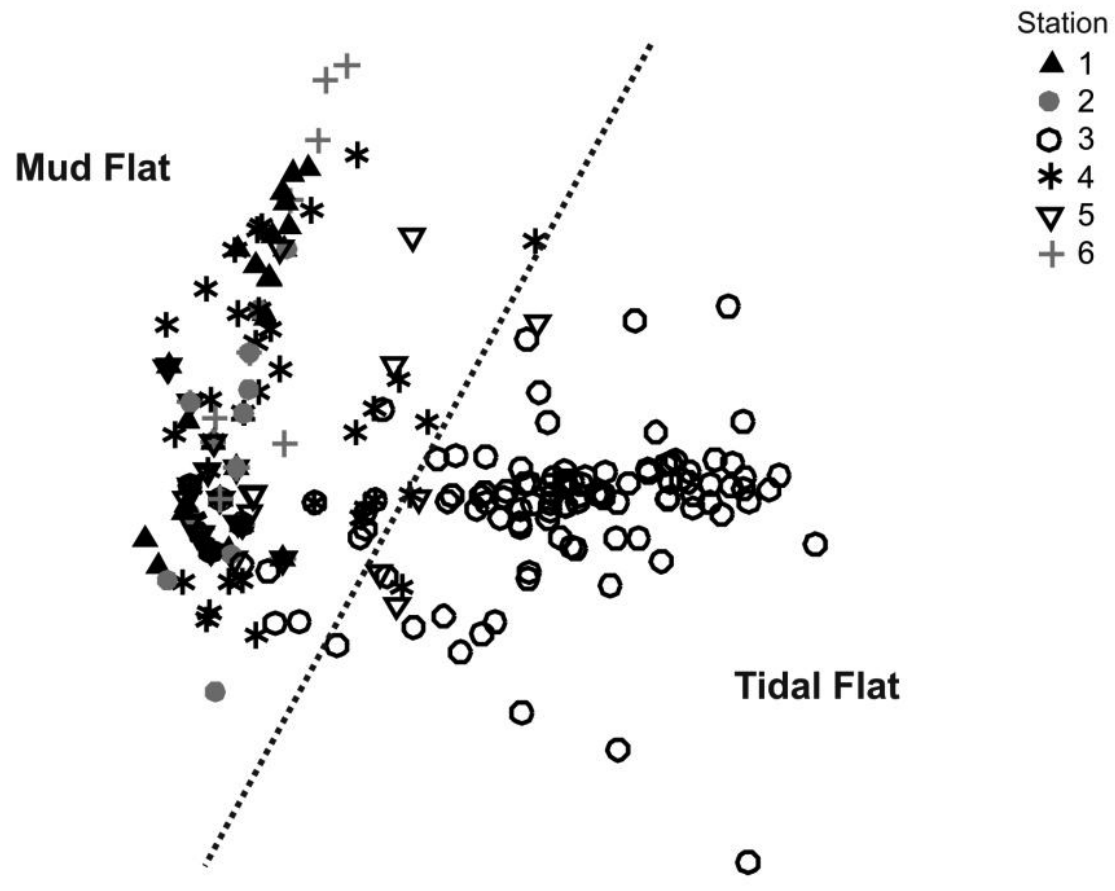

Figure 4. Non-metric multidimensional scaling (n-MDS) ordination plots based on Bray-Curtis similarities. Station 3 located in a sand tidal flat stood out from the other stations.

Table 2. SIMPER - Similarity percentage contribution of species for each association.

\begin{tabular}{|c|c|c|c|c|c|}
\hline Association & Species & $\begin{array}{c}\text { Average } \\
\text { Abundance }\end{array}$ & $\begin{array}{c}\text { Average } \\
\text { Similarity }\end{array}$ & $\begin{array}{c}\text { Species } \\
\text { Contribution }\end{array}$ & $\begin{array}{c}\text { Cumulative } \\
\text { Contribution }\end{array}$ \\
\hline \multirow[t]{10}{*}{ Mud Bottom (1.69)* } & Macoma uruguayensis & 0.12 & 0.58 & 33.97 & 33.97 \\
\hline & Cylichna verrilli & 0.27 & 0.49 & 29.01 & 62.98 \\
\hline & Tagelus divisus & 0.05 & 0.36 & 21.45 & 84.43 \\
\hline & Acteocina candei & 0.07 & 0.09 & 5.02 & 89.45 \\
\hline & Anomalocardia brasiliana & 0.05 & 0.06 & 3.34 & 92.79 \\
\hline & Tellina lineata & 0.02 & 0.03 & 1.77 & 94.57 \\
\hline & Tellina versicolor & 0.03 & 0.03 & 1.51 & 96.08 \\
\hline & Nucula semiornata & 0.02 & 0.02 & 1.25 & 97.32 \\
\hline & Bulla striata & 0.02 & 0.01 & 0.66 & 97.98 \\
\hline & Nassarius vibex & 0.01 & 0.01 & 0.54 & 98.52 \\
\hline \multirow[t]{6}{*}{ Sand Tidal Flat $(30.80) *$} & Anomalocardia brasiliana & 7.88 & 27.8 & 90.26 & 90.26 \\
\hline & Tellina lineata & 0.63 & 1.21 & 3.94 & 94.2 \\
\hline & Polyplacophora & 0.6 & 0.83 & 2.7 & 96.9 \\
\hline & Tagelus divisus & 0.14 & 0.18 & 0.58 & 97.48 \\
\hline & Cerithium atratum & 0.13 & 0.14 & 0.45 & 97.93 \\
\hline & Crepidula pyguaia & 0.62 & 0.13 & 0.43 & 98.36 \\
\hline
\end{tabular}

*Association similarity.

an increase in mean richness (Figures 5a and 6). The species-area curves indicate that, despite Sand Tidal Flat association having a lesser number of samples (one station against five from Mud Bottom association), it had the highest species richness along with an exponential tendency. In contrast, the Mud Bottom association had a lower number of species and tended to reach an asymptote (Figure 7).

\section{Discussion}

The sediment composition at Saco dos Limões embayment was similar to that previously described by Schettini et al. (2002). The higher contribution of clay in the Mud Bottom areas between 2003 and 2004 surveys may be associated with the construction of the express highway that lasted from 1996 to 2005 . Following this period, the contribution of clay from terrestrial origin decreased with a major contribution of silt, probably from natural origin.

The characteristics of sediment explained the species associations. The Mud Bottom association was characterized by low abundance and a variable fauna composition at the different stations and at different times. On the other hand, the Sand Tidal Flat association had higher abundance and diversity, showing higher similarity between surveys 

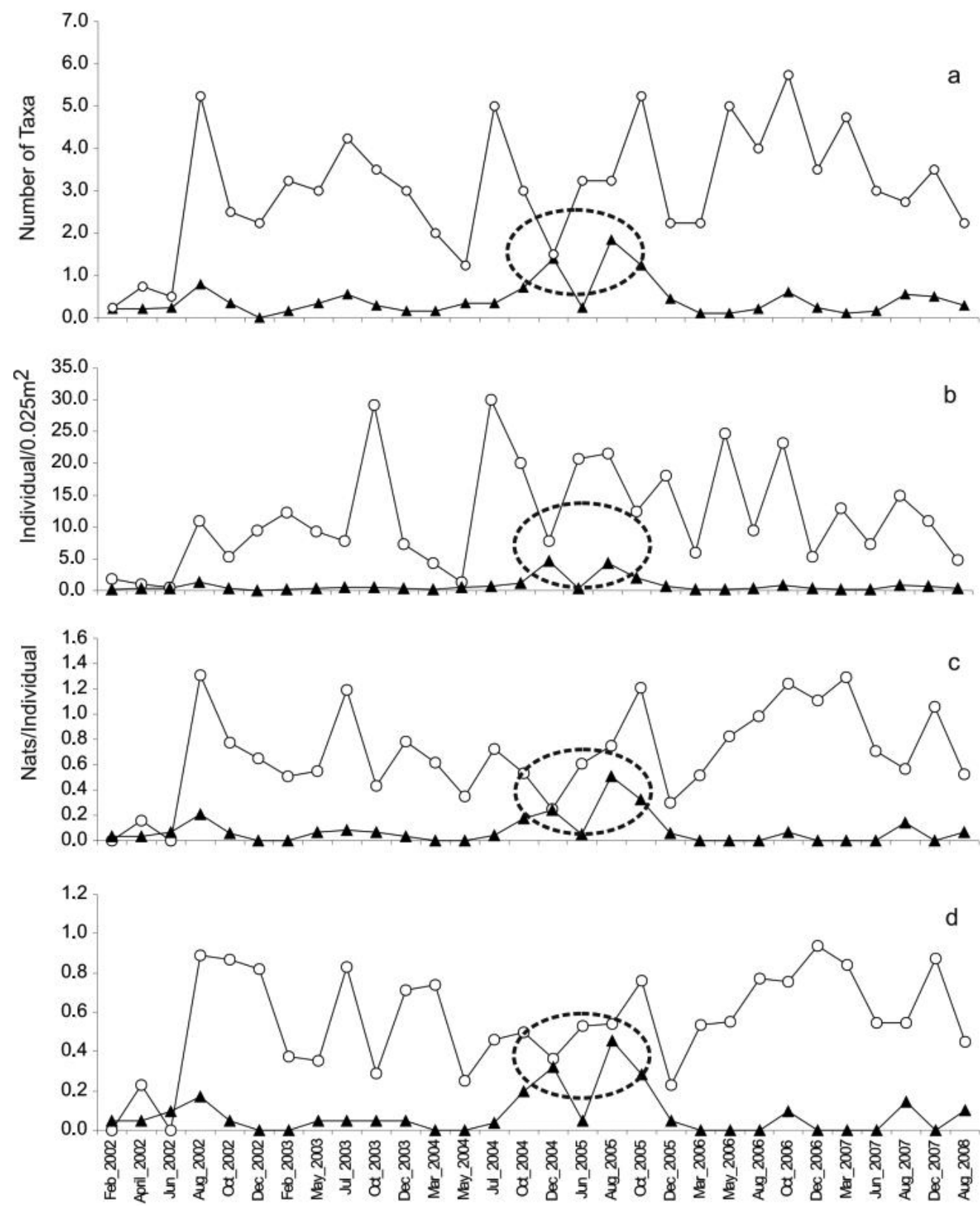

Figure 5. Mean values of richness (a), abundance (b), Shannon Wiener's diversity (c), and Pielou's equitability (d) on the Sand Tidal Flat association ( $\circ$ ) and Mud Bottom association ( $\boldsymbol{\Delta}$ ) of South Bay, Florianópolis Island, between February 2002 and August 2008.

Table 3. ANOVA - Analysis of variance. Degrees of freedom (DF), Mean Square (MS), and F and p values for each factor of ecological indexes.

\begin{tabular}{|c|c|c|c|c|c|}
\hline Variable & Factors & DF & MS & $\mathbf{F}$ & $\mathbf{p}$ \\
\hline \multirow[t]{3}{*}{ Richness } & Survey & 29 & 8.15 & 8.73 & $* * *$ \\
\hline & Association & 1 & 695.20 & 744.62 & $* * *$ \\
\hline & Survey*Association & 29 & 6.77 & 7.25 & $* * *$ \\
\hline \multirow[t]{3}{*}{ Abundance } & Survey & 29 & 0.58 & 11.64 & $* * *$ \\
\hline & Association & 1 & 64.69 & 1303.82 & $* * *$ \\
\hline & Survey*Association & 29 & 0.43 & 8.59 & $* * *$ \\
\hline \multirow[t]{3}{*}{ Shanon-Wiener diversity } & Survey & 29 & 0.53 & 6.67 & $* * *$ \\
\hline & Association & 1 & 36.76 & 466.77 & $* * *$ \\
\hline & Survey*Association & 29 & 0.47 & 5.93 & $* * *$ \\
\hline \multirow[t]{3}{*}{ Pielou Equitability } & Survey & 29 & 0.26 & 4.29 & $* * *$ \\
\hline & Association & 1 & 22.39 & 373.17 & $* * *$ \\
\hline & Survey*Association & 29 & 0.28 & 4.70 & $* * *$ \\
\hline
\end{tabular}




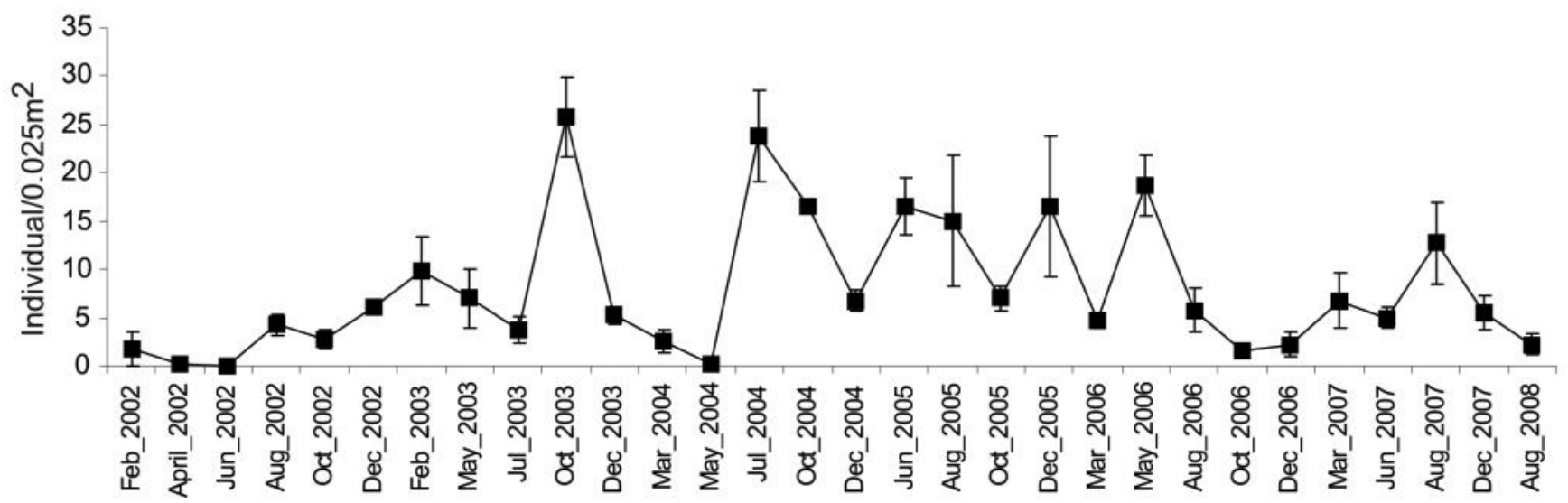

Figure 6. Mean and standard error for density values (individual $/ 0,025 \mathrm{~m}^{2}$ ) of $A$. brasiliana at station 3 on all sampling surveys.

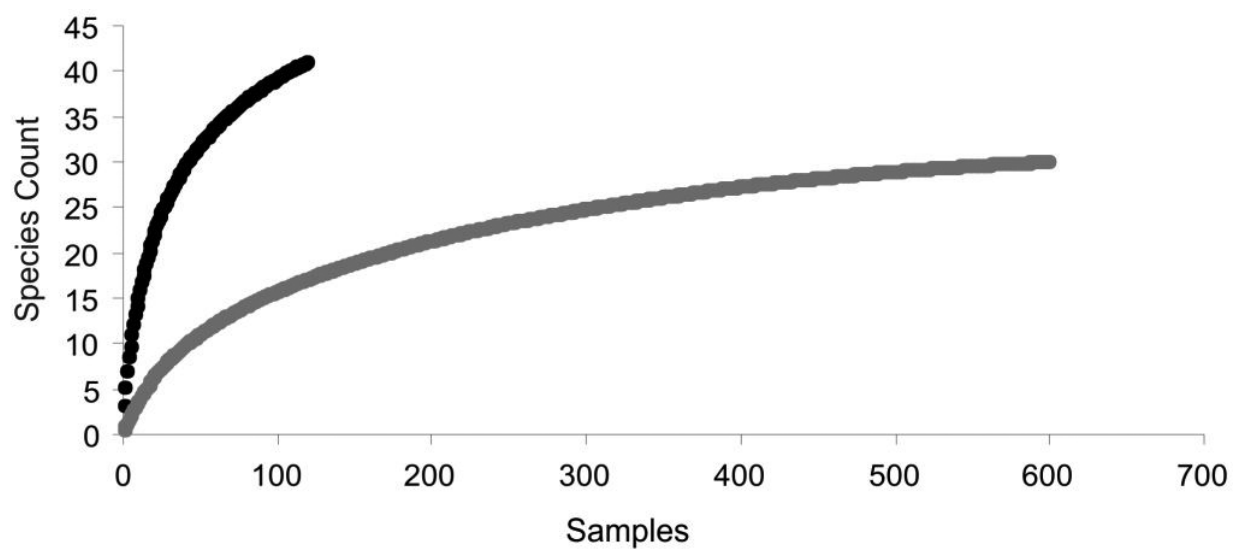

Figure 7. Species observed (Sobs) accumulation curves per samples after 999 permutations for Sand Tidal Flat association $(\bullet)$ and Mud Bottom association $(\bullet)$ in South Bay, Florianópolis Island.

in terms of faunistic composition. The presence of fine sand, silt, and a large amount of live mussels and mussel shell fragments on the tidal flat, which reflects on greater sediment heterogeneity, could explain this higher diversity of species. Mussel beds play an important role in regulating macrofaunal diversity in soft-bottom habitats (Commito et al. 2008) as compared to sediments with homogeneous characteristics (Levinton 1995, Rufino et al. 2008).

The two associations were also different regarding the species feeding habits. The Mud Bottom association was mainly composed of deposit feeders (M. uruguaiensis, T. lineata, Tellina versicolor and Nucula semiornata), suspension feeders ( $T$. divisus and $A$. brasiliana), and carnivores (C. verrilli, A. candei, Bulla striata, and Nassarius vibex) (Rios 2009, Arruda et al. 2003). The deposit feeders and carnivores relation with fine sediments has already been reported to Santa Catarina state (Almeida et al. 2004). The higher number of carnivores can be associated with the prey availability, like some opportunistic deposit-feeding polychaeta from the family Capitellidae and Spionidae that can be abundant in these habitats (Commito et al. 2008), specially at organic enriched environments. The Sand Tidal Flat association was mainly composed of suspension feeders (A. brasiliana, T. divisus, and C. pyguaia), deposit feeders (T. lineata), and herbivores (Polyplacophora and Cerithium atratum) (Rios 2009, Arruda et al. 2003). The suspension feeders were already associated with sand sediment in Santa Catarina state (Almeida et al. 2004). The presence of herbivores on the tidal flat area can be explained by the large amount of live mussels and mussel shell hash of $A$. brasiliana. These structures associated with the low water depth allow attachment of a bacterial film and the incrustation of algae, which do not usually occur when silt is predominant. Arruda et al. (2003) found C. atratum only at sites that had a higher contribution of fine sand and gravel with encrusted algae.

In addition to the spatial variation, we noticed great temporal fluctuations of the benthic associations. Winter months usually had higher species richness and abundance values. In this study, we have associated this high abundance with the increase of $A$. brasiliana density, which has its reproductive period mainly during the cold months (Pezzuto \& Echternacht 1999, Boehs et al. 2008). The recruits settling during fall and winter months would be favored by a decrease in the stock of adults during summer months. This decrease can be related to higher rainfall. The rainfall may cause abrupt changes in salinity (osmotic shock) and resuspension of bottom sediment, which might be inadequate for these shellfish (Boehs et al. 2008). In Guadalupe (French West Indies), a high mortality rate of $A$. brasiliana was observed after intense periods of rain (Monti et al. 1991). Although $A$. brasiliana has a negative response to excessive rain; it shows a fine adaptation to organic enrichment (Boehs et al. 2008).

The winter of 2005 showed an increase in diversity and also higher rainfall and temperature. The highest amount of rainfall could be responsible for the increase in concentration of organic matter from mangroves and sewage input into the embayment. This increase could result in a higher productivity in water and sediment (Levinton 1995). On the other hand, the highway building finished in 2005 and probably changed the structure of the mollusc associations as a result of the cessation of sediment input from the building activities. 
In the following years, all community descriptors showed a different pattern from that of the previous years, with a gradual increase of parameter settings and lower amplitude of variation between seasons. This rapid recolonization is an evidence of the importance of having protected areas next to urban regions, which can work as exportation areas of biodiversity. These results also suggest that the sand tidal flat, which is protected by the RESEX, could maintain the diversity of adjacent areas.

The Brazilian coast has a great amount of tidal flats with similar characteristics to those found at the RESEX of Pirajubaé (pers. obs). The presence of sandy and mud tidal flats nearby mangroves is common in tropical and temperate regions throughout the world (Dittmann 2002). At the same time, little is known about the macrobenthic ecology of sand tidal flats in subtropical regions. The hypothesis that tropical tidal flats have higher richness and lower abundance than temperate tidal flats is substantiated by Dittmann (2000). Tropical tidal flats can support high levels of diversity and a large amount of rare species (Dittmann 2002, Winberg et al. 2007), usually with low species frequency and exponential species-area curves (Reise 1991). However, the Pirajubaé's sand tidal flat have high mollusc diversity and an exponential species-area curve even with the extraction of molluscs and urbanization pressure.

The planning and supervision of extractive activities and actions to reduce pollution should be considered [as already indicated by Souza et al. (2012) in a water quality evaluation of Florianópolis South Bay] so that the RESEX can effectively contribute to the biodiversity conservation at a local and regional level. As the present study showed, higher diversity of molluscs can be found at the sand tidal flat when compared with adjacent mud sediments, even in an urban bay. However, there is a clear need for studies focusing on diversity characterization of other sand tidal flats, especially at the subtropical latitudes. More attention to the conservation of sand tidal flats should be considered, mostly because of their diversity; location in transitional zones between marine, freshwater, and terrestrial ecosystems; connection with mangrove forests; great economic, social, and cultural importance for local communities; and high anthropogenic pressure due to the urban development in coastal areas. The existence of protected areas in coastal regions is well known as one of the key tools for conservation and management of habitats (García Charton et al. 2000, Fernandez et al. 2000, Skov et al. 2007).

\section{Acknowledgments}

The authors would like to thank all the colleagues from the Laboratory of Ecology of Aquatic Communities (UNIVALI) who helped in the field and laboratory work and to EPAGRI (Empresa de Pesquisa Agropecuária e Extenção Rural de Santa Catarina, Brazil) who provided the climate data from 2002 to 2008 . This work is part of a monitoring program funded by the National Department of Transport Infrastructure of Santa Catarina, Brazil (DNIT/SC).

\section{References}

ALMEIDA, T.C.M., ROHR, T.E. \& SCHIO, C. 2004. Associações de moluscos do infralitoral de Santa Catarina, SC - Brasil. Notas Tec. Facimar 8:119-126.

ANDERSON, M.J. 2001. A new method for non-parametric multivariate analysis of variance. Austral Ecol. 26:32-46.

ANDERSON, M.J. 2005. PERMANOVA: a FORTRAN computer program for permutational multivariate analysis of variance. University of Auckland, New Zealand.

ARRUDA, E.P., DOMANESCHI, O. \& AMARAL, A.C.Z. 2003. Mollusc feeding guilds on sandy beaches in São Paulo State, Brazil. Mar. Biol. 143:691-701. http://dx.doi.org/10.1007/s00227-003-1103-y
ARRUDA, E.P. \& DOMANESCHI, O. 2005. New species of Macoma (Bivalvia: Tellinoidea: Tellinidae) from southeastern Brazil, with description of its gross anatomy. Zootaxa 1012:13-22.

BEMVENUTI, C.E., ANGONESI, L.G. \& GANDRA, M.S. 2005. Effects of dredging operations on soft bottom macrofauna in a harbor in the Patos lagoon estuarine region of southern Brazil. Braz. J. Biol. 65(4):573-581. http://dx.doi.org/10.1590/S1519-69842005000400003

BOEHS, G., ABSHER, T.M. \& CRUZ-KALED, A.C. 2008. Ecologia populacional de Anomalocardia brasiliana (Gmelin 1791) (Bivalvia, Veneridae) na Baía de Paranaguá, Paraná, Brasil. Bol. Inst. Pesca 34(2):259-270.

BOLAM, S.G., REES, H.L., SOMERFIELD, P., SMITH, R., CLARKE, K.R., WARWICK, R.M., ATKINS, M. \& GARNACHO, E. 2006. Ecological consequences of dredge material disposal in the marine environment: a holistic assessment of activities around the England and Wales coastline. Mar. Pollut. Bull. 52:415-426. http://dx.doi.org/10.1016/j. marpolbul.2005.09.028

BRAZEIRO, A. \& DEFEO, O. 1999. Effects of harvesting and densitydependence on the demography of sandy beach populations: the yellow clam Mesodesma mactroides of Uruguay. Mar. Ecol. Prog. Ser. 182:127 135. http://dx.doi.org/10.3354/meps 182127

CANNICCI, S., BARTOLINI, F., DAHDOUH-GUEBAS, F., FRATINI, S., LITULO, C., MACIA, A., MRABU, E.J., PENHA-LOPES, G. \& PAULA, J. 2009. Effects of urban wastewater impact on crab and mollusc assemblages in equatorial and subtropical mangroves of East Africa. Estuar. Coast. Shelf Sci. 84:305-317. http://dx.doi.org/10.1016/j. ecss.2009.04.021

CLARKE, K.R. \& WARWICK, R.M. 2001. Changes in marine communities: an approach to statistical analysis and interpretation. 2nd ed. PRIMER-E, Plymouth.

COLLIE, J.S., HALL, S.J., KAISER, M.J. \& POINER, I.R. 2000. A quantitative analysis of fishing impacts on shelf-sea benthos. J. Anim. Ecol. 69:785-798. http://dx.doi.org/10.1046/j.1365-2656.2000.00434.x

COMMITO, J.A., COMO, S., GRUPE, B.M. \& DOW, W.E. 2008. Species diversity in the soft-bottom intertidal zone: biogenic structure, sediment, and macrofauna across mussel bed spatial scales. J. Exp. Mar. Biol. Ecol. 366:70-81. http://dx.doi.org/10.1016/j.jembe.2008.07.010

DITTMANN, S. 2000. Zonation of benthic communities in a tropical tidal flat of north-east Australia. J. Sea Res. 43:33-51. http://dx.doi.org/10.1016/ S1385-1101(00)00004-6

DITTMANN, S. 2002. Benthic fauna in tropical tidal flats - a comparative perspective. Wetl. Ecol. Manag. 10:189-195. http://dx.doi. org/10.1023/A:1020119512225

FERNANDEZ, M., JARAMILLO, E., MARQUET, P.A., MORENO, C.A., NAVARRETE, S.A., OJEDA, F.P., VALDOVINOS, C.R. \& VASQUEZ, J.A. 2000. Diversity, dynamics and biogeography of Chilean benthic nearshore ecosystems: an overview and guidelines for conservation. Rev. Chil. Hist. Nat. 73(4):797-830. http://dx.doi.org/10.4067/S0716078X2000000400021

FOLK, R.L. \& WARD, W.C. 1957. Brazos River Bar: a study in the significance of grain size parameters. J. Sediment Petrol. 27(1):3-26. http://dx.doi.org/10.1306/74D70646-2B21-11D7-8648000102C1865D

GARCÍA CHARTON, J.A., WILLIAMS, I.D., PÉREZ-RUZAFA, A., MiLAZZO, M., CHEMELlO, R., MARCOS, C., KITSOS, M.S., KOUKOURAS, A. \& RIGGIO, S. 2000. Evaluating the ecological effects of Mediterranean marine protected areas: habitat, scale and the natural variability of ecosystems. Environ. Conserv. 27(2):159-178. http://dx.doi. org $/ 10.1017 /$ S0376892900000199

GASPAR, M.B., LEITÃO, F., SANTOS, M.N., CHÍCHARO, L., DIAS, M.D., CHÍCHARO, A. \& MONTEIRO, C.C. 2003. A comparison of direct macrofaunal mortality using three types of clam dredges. J. Mar. Sci. 60:733-742.

GRAY, J.S., DAYTON, P., THRUSH, S. \& KAISER, M.J. 2006. On effects of trawling, benthos and sampling design. Mar. Pollut. Bull. 52:840-843. http://dx.doi.org/10.1016/j.marpolbul.2006.07.003 
GUERRA-GARCÍA, J.M. \& GARCÍA-GÓMEZ, J.C. 2004. Soft bottom mollusc assemblages and pollution in a harbour with two opposing entrances. Estuar. Coast. Shelf Sci. 60:273-283. http://dx.doi. org/10.1016/j.ecss.2004.01.004

INGLIS, G.J. \& KROSS, J.E. 2000. Evidence for systemic changes in the benthic fauna of tropical estuaries as a result of urbanization. Mar. Pollut. Bull. 41(7-12):367-376.

LEGENDRE, P. \& LEGENDRE, L. 1998. Numerical Ecology. 2nd ed. Elsevier, Amsterdam.

LEVINTON, J.S. 1995. Marine Biology: function, biodiversity, ecology. 2nd ed. Oxford University Press, New York.

McARDLE, B.H. \& ANDERSON, M.J. 2001. Fitting multivariate models to community data: a comment on distance-based redundancy analysis. Ecol. 82:290-297. http://dx.doi.org/10.1890/00129658(2001)082[0290:FMMTCD]2.0.CO;2

MONTI, D., FRENKIEL, L. \& MOUEZA, M. 1991. Demography and growth of Anomalocardia brasiliana (Gmelin) (Bivalvia, Veneridae) in a mangrove, in Guadaloupe (French West Indies). J. Molluscan Stud. 57:249-257. http://dx.doi.org/10.1093/mollus/57.2.249

MORTON, B. 1996. The subsidiary impacts of dredging (and trawling) on a subtidal benthic molluscan community in the southern waters of Hong Kong. Mar. Pollut. Bull. 32(10):701-710. http://dx.doi.org/10.1016/0025326X(96)00002-1

NEWELL, R.C., SEIDERER, L.J. \& HITCHCOCK, D.R. 1998. The impact of dredging works in coastal waters: a review of the sensitivity to disturbance and subsequent recovery of biological resources on the sea bed. Oceanogr. Mar. Biol. Annu. Rev. 36:127-178.

PEZZUTO, P.R. \& ECHTERNACHT, A.M. 1999. Avaliação de impactos da construção da Via Expressa SC-Sul sobre o berbigão A. brasiliana (Gmelin, 1791) (Mollusca: Pelecypoda) na Reserva Extrativista Marinha do Pirajubaé (Florianópolis, SC-Brasil). Atlântica 21:105-119.

PEZZUTO, P.R., SCHIO, C. \& ALMEIDA, T.C.M. 2010. Efficiency and selectivity of the Anomalocardia brasiliana (Mollusca: Veneridae) hand dredge used in southern Brazil. J. Mar. Biol. Assoc. U.K. 90:1455-1464. http://dx.doi.org/10.1017/S0025315410000317

R DEVELOPMENT CORE TEAM. http://www.R-project.org. (último acesso em 09/08/2012).

REISE, K. 1991. Macrofauna in mud and sand of tropical and temperate tidal flats. In Estuaries and Coasts: Spatial and Temporal Intercomparisons (M. Elliott \& J.P. Ducrotoy, eds.). Olsen and Olsen, Fredensborg, p. 211-216.

RIBAS, L.C.C. \& ZUCULOTO, J.R.M. 2012. Os extrativistas da Reserva Extrativista Marinha do Pirajubaé (Florianópolis, Santa Catarina, Brasil) - visões endógenas sobre a reserva e o turismo local. Tur. \& Soc. 5(2):391-422.

RIOS, E.C. 2009. Compendium of Brazilian sea shells. Evangraf, Rio Grande.
RUFINO, M.M., GASPAR, M.B., MAYNOU, F. \& MONTEIRO, C.C. 2008. Regional and temporal changes in bivalve diversity off the south coast of Portugal. Estuar. Coast. Shelf Sci. 80:517-528. http://dx.doi.org/10.1016/j. ecss.2008.09.014

SCHETTINI, C.A.F., PEREIRA, J. \& SPILLERE, L. 2000. Caracterização oceanográfica e biogeoquímica dos estuários dos Rios Tavares e Defuntos, Reserva Extrativista de Pirajubaé, Florianópolis, SC. Notas Tec. Facimar 4:11-28.

SCHETTINI, C.A.F., SANTOS, M.I.F. \& ABREU, J.G.N. 2002. Observação dos sedimentos de fundo de uma plataforma abrigada sob influência de atividade de dragagem: Saco dos Limões, Florianópolis, SC. Notas Tec. Facimar 6:165-175.

SIMONE, L.R.L. 2006. Morphological and phylogenetic study of the Western Atlantic Crepidula plana complex (Caenogastropoda, Calyptraeidae), with description of three new species from Brazil. Zootaxa 1112:1-64.

SKILLETER, G.A. \& WARREN, S. 2000. Effects of habitat modification in mangroves on the structure of mollusc and crab assemblages. J. Exp. Mar. Biol. Ecol. 244:107-129. http://dx.doi.org/10.1016/S00220981(99)00133-1

SKOV, H., DURINCK, J., LEOPOLD, M.F. \& TASKER, M.L. 2007. A quantitative method for evaluating the importance of marine areas for conservation of birds. Biol. Conserv. 136:362-371. http://dx.doi. org/10.1016/j.biocon.2006.12.016

SOUZA, D.S.M., RAMOS, A.P.D., NUNES, F.F., MORESCO, V., TANIGUCHI, S., LEAL, D.A.G., SASAKI, S.T., BICEGO, M.C., MONTONE, R.C., DURIGAN, M., TEIXEIRA, A.L., PILOTTO, M.R., DELFINO, N., FRANCO, R.M.B., MELO, C.M.R., BAINY, A.C.D. \& BARARDI, C.R.M. 2012. Evaluation of tropical water source sand mollusks in southern Brazil using microbiological, biochemical, and chemical parameters. Ecotoxicol. \& Environ. Saf. 76:153-161. http:// dx.doi.org/10.1016/j.ecoenv.2011.09.018

UNDERWOOD, A.J. 1997. Experiments in Ecology. Cambridge University Press, New York.

VIVAN, J.M., DOMENICO, M. \& ALMEIDA, T.C.M. 2009. Effects of dredged material disposal on benthic macrofauna near Itajaí Harbour (Santa Catarina, South Brazil). Ecol. Eng. 35:1435-1443. http://dx.doi. org/10.1016/j.ecoleng.2009.06.005

VIZINHO, S.C. \& TOGNELLA-DE-ROSA, M.M.P. 2010. Socio-economic and cultural analysis of the Pirajubaé fishing community (Baía Sul-Florianópolis - Santa Catarina - Brazil): A Tool for integrated coastal management. J. Integr. Coast. Zone Manag. SI(2):1-9.

WINBERG, P.C., LYNCH, T.P., MURRAY, A., JONES, A.R. \& DAVIS, A.R. 2007. The importance of spatial scale for the conservation of tidal flat macrobenthos: An example from New South Wales, Australia. Biol. Conserv. 134:310-320. http://dx.doi.org/10.1016/j.biocon.2006.07.019

WHOMERSLEY, P., SCHRATZBERGER, M., HUXHAM, M., REES, H.L. $\&$ BATES, H. 2007. The use of time series data in the assessment of macrobenthic community change after the cessation of sewage sludge disposal in Liverpool Bay (UK). Mar. Pollut. Bull. 54:32-41. http://dx.doi. org/10.1016/j.marpolbul.2006.07.008 